\title{
HYPERBARIC OXYGEN THERAPY [HBOT]
}

\author{
Lt Col YOGESH CHANDER * , Surg Cdr RN MISRA *, \\ Col RAMJI RAI ${ }^{\#}$
}

MJAFI 1999; 55 : $89-90$

$\mathbf{W}$ ith exception to obligatory anaerobic organisms the requirement of oxygen to sustain life and normal functions is absolute for all known organisms on the earth. Oxygen is required for energy producing biochemical reactions within the cell and is therefore essential for all life sustaining functions. Oxygen deficiency can seriously impair vital functions at cellular levels.

The therapeutic use of oxygen was suggested by its discoverer, Priestley in 1775 and since that time the gas has been used as therapeutic agent most extensively. The gas administered through catheters, tents and masks is usually slightly higher than normal atmospheric pressure at sea level barometric pressure of $760 \mathrm{~mm}$ of $\mathrm{Hg}$ i.e. one Absolute Atmosphere [1 ATA]. The Hyperbaric oxygen therapy i.e. 100\% oxygen is administered in the monoplace or multiplace chambers fitted with oxygen delivery system and monitoring equipment at a pressure two to three times the atmospheric pressure at sea level [2-3 ATA]. The oxygen at this pressure increases arterial oxygen tension more than $2000 \mathrm{~mm}$ of $\mathrm{Hg}(1)$ and oxygen tension in tissue of almost $400 \mathrm{~mm}$ of $\mathrm{Hg}[2,3]$.

At sea level the blood oxygen concentration is 0.3 $\mathrm{ml} / \mathrm{dl}[1,4]$. Tissue at rest draw 5 to $6 \mathrm{ml}$ of oxygen per deciliter of blood assuming normal perfusion $[1,5]$. Administering $100 \%$ oxygen at normobaric pressure increases the amount of oxygen dissolved in the blood to $1.5 \mathrm{ml} / \mathrm{dl}$ (five folds) and at 3 ATA the dissolved oxygen content is approximately $6 \mathrm{ml} / \mathrm{dl}$, much more than the resting cellular requirement [1].

The oxygen at this tension has a number of beneficial biochemical, cellular and physiological effects which make it a logical adjunct for the management of various syndromes.

The primary and single most important effect of $\mathrm{HBO}$ is hyperoxygenation which result in three fold increase of diffusion distance of oxygen through the tissues thus having anti-ischemic effect . HBO also improves the angiodynamics and red cell rheology [6]. This contributes to the improvement of microcirculation and reduces oedema upto approximately $20 \%$ in the injured part.

Local hypoxia predisposes wound to infection because the neutrophil mediated killing of bacteria by free radical is decreased $[7,8]$ which is restored by HBOT. In addition HBO is bactericidal for anaerobes [9] and bacteriostatic for aerobes $[10,11,12]$. HBO promotes the formation of collagen matrix and angiogenesis thus hasten the process of healing [13]. HBO protects tissue from reperfusion injury [6] through increased cell re-oxygenation induced detoxifying toxic radical processes, prevention of cell membrane lipid peroxidation and reduced leucocyte tissue sequestration and leucocyte related injury. HBO at 2-3 ATA reduces the half life of carboxyhemoglobin from 4 to 5 hours in subjects breathing normal air to $20 \mathrm{~min}$ or less [14]. Thus have beneficial action in carbon monoxide poisoning. The HBO dissociates carbon monoxide from cytochrome ' $\mathrm{C}$ ' oxidase thus preventing cellular asphyxiation [15].

These physiological and biochemical effects of HBO can beneficially influence the therapeutics of various syndromes. Current therapeutic uses are Carbon monoxide poisoning, Decompression sickness, Arterial gas embolism, Radiation induced tissue injuries, Clostridial myonecrosis, Necrotizing fascitis, Refractory oesteomyelitis, Acute traumatic ischemic injury, Compromised skin grafts and flaps, Anaemia due to blood loss, Thermal burns and problem wounds like Diabetic foots and Leg ulcers due to arterial deficiency. The effectiveness of HBOT in mycobacterial diseases is under study and De Sylva et al [16] have studied HBOT as an adjunct to Multidrug therapy in Hansen's disease. They have found beneficial effect of adjunct HBOT therapy, in that there is reduction in erythema of the lesions, flattening of the lesions, improvement in the sensory perception, decrease in the

\footnotetext{
"Reader, Department of Microbiology, "Professor \& Head, Department of Pathology, Armed Forces Medical College, Pune 411040.
} 
nerve thickening and cellular infilterate and fall in the bacillary index. Gottlieb [17] and Youngblood [18] also have found HBOT effective in Hansen's disease.

Effective HBOT is given either in monoplace chamber or multiplace chamber. Duration of single treatment varies from $45 \mathrm{~min}$ for carbon monoxide poisoning to $5 \mathrm{hrs}$ for severe decompression disorders. Protocols average $90 \mathrm{~min}$ for each of 20 to 30 treatments with HBO as an adjunct therapy of the wounds and other syndromes. De Sylva et al has used multiplace hyperbaric chamber and HBOT at 2.2 ATA for 60 min daily for 12 days was administered.

HBOT at pressures not exceeding 3 ATA and treatment sessions limited to 120 minute is safe. Some adverse effects like reversible myopia is the most common side effect and others are barotrauma and generalised seizures which are rare [9]. With repeated exposure to HBO some patients has tracheobronchial symptoms with concomitant reversible decrements in pulmonary functions. Claustrophobia can be problem in monoplace chambers.

HBO has been described as a therapy in search of diseases [20]. The discovery of beneficial cellular and biochemical effects has strengthened the rationale for administering $\mathrm{HBO}$ as primary therapy or as adjunct therapy in many of the diseases, where as there is less scientific support for the other uses of HBO but reports of favourable effects support many of them and thus still requires more scientific controlled studies.

\section{REFERENCES}

1. Lambertsen CJ, Kough RH, Cooper DY. Emmel GL. Loeschcke HH, Schmidt CF. Oxygen toxicity: effects in man in oxygen inhalation at 1 and 3.5 atmospheres upon blood gas transport, cerebral circulation and cerebral metabolism. J Appl Physiol 1953;5:471-86.

2. Mader JT, Brown GL. Guckian JC, Wells CH, Reinarz JA. A mechanism for the amelioration by hyperabaric oxygen of experimental Staphylococcal osteomyelitis in rabbits. J Infegct Dis 1980;142:915-22.

3. Marx RE, Johnson RP. Problem wounds in oral and maxillofacial surgery; the role of hyperbaric oxygen in Davis JC, Hunt TK, eds. Problem wounds-the role of oxygen. New York; Elsevier 1988;65-123.

4. Boerema I, Meyne NG, Brummelkamp WK, et al. Life without blood: a study of the influence of high atmospheric pres- sure and hyperthermia on dilution of the blood. J Cardiovase Surg 1960;1:133-46.

5. Kety SS, Schmidt CF. The effects of altered arterial tension of carbon dioxide and oxygen on cerebral blood flow and cerebral oxygen consumption of normal young men. J Clin Invest 1948;27:484-92.

6. Andel H, Felfernig M, Andel D, Blaicher W, Schramm W. Hyperbaric oxygen therapy in osteomyelitis. Anaesthesia 1998;53(2):68-9.

7. Hunt TK. The physiology of wound healing. Ann Emerg Med 1988;17:1265-73.

8. Knighton DR, Halliday B, Hunt TK. Oxygen as an antibiotic: a comparison of the effects of inspired oxygen concentration and antibiotic administration on in vivo bacterial clearance. Arch Surg 1986;121:191-5.

9. Hill GB, Osterhout S. Experimental effects of hyperbaric oxygen on selected clostridial species. I In vitro studies. J Infect Dis 1972;125:17-25.

10. Boehm DE, Vincent $K$, Brown OR. Oxygen and toxicity inhibition of amino acid biosynthesis. Nature 1976;262:418-20.

11. Brown OR. Reversible inhibition of respiration of Escherichia coli by hyperoxia. Microbics 1972;5:7-16.

12. Park MK, Muhvich KH, Myers RAM, Marzella L. Hyparoxia prolongs the aminoglycoside induced post antibiotic effect in Psedomonas aerogenosa. Antimicrobe Agents Chemother 1991;35:691-5.

13. Prockop DJ. Kivirikko KI. Tuderman L. Guzman NA. The biosynthesis of collagen and its disorders. N Engl J Med 1979;301:13-23: 77-85.

14. Pace N, Strajman E, Walker EL. Accleration of carbon monoxide elimination in man by high pressure oxygen, Science 1950;111:652-4.

15 Brown SD, Piantadosi CA. In vivo binding of carbon monoxide to cytochrome $\mathrm{C}$ oxide in rat brain $\mathrm{J}$ Appl Physiol 1990;68:604-10.

16. De Sylva PLK, Nangpal S, John MJ, et al. Therapeutic Hyperbaric oxygenation as an adjunct to multidrug therapy in Hansen's disease. MJAFI 1998;55(2):....

17. Gottlieb SF. Oxygen under pressure and micro-organisms. In: Ed-Davies JC and Hunt TK eds. Hyperbaric oxygen Therapy Bethesda, Maryland Undersea Hyperbaric Medical Society 1988.

18. Youngblood DA. Hyberbaric oxygen in the treatment of Hansen's disease. Hyperbaric oxygen Review 1984;5(4): 244-50.

19. Clark JM, Robin ED. Hyperbaric oxygen a therapy in search of diseases. Chest 1987;92:1074-82.

20. Gabb G, Robin ED. Hyperbaric oxygen: a therapy in search of diseases. Chest 1987;92:1074-82. 